Jurnal Spektrum Komunikasi Vol. 8 No. 2 , Desember 2020

\title{
PERAN INFLUENCER SEBAGAI KOMUNIKASI PERSUASIF UNTUK PENCEGAHAN COVID-19
}

\section{THE ROLE OF INFLUENCER AS PERSUASIVE COMMUNICATION FOR COVID- 19 PREVENTION}

\author{
Sukma Alam \\ Program Studi Ilmu Komunikasi Universitas Budi Luhur \\ Email: sukma.alam@budiluhur.ac.id
}

\begin{abstract}
The existence of influencers is important in information disclosure in the midst of the COVID-19 pandemic. Because, influencers are people who have influence in disseminating information and experiences in a persuasive manner. This study used a case study method with informant interviews, namely two influencers who were officially partnered with BNPB. The COVID-19 Task Force. The results of this study show that the role of influencers has a significant impact on their followers. Content created by influencers in an effort to prevent COVID-19, uses an approach that is persuasive or solicitous in that each content is inserted with education and prevention socialization as well as content that does not contain conversion. To reach people who cannot access the internet, influencers go to the field to communicate directly to meet community leaders, public figures and regional heads. This creates trust between users and their followers, so these influencers have succeeded in having loyal followers.
\end{abstract}

Keywords: Influencers, Persuasive Communication, COVID-19

\begin{abstract}
ABSTRAK
Keberadaan influencer itu penting dalam keterbukaan informasi di tengah pandemi COVID-19. Karena, influencer salah seorang yang mempunyai pengaruh dalam menyebarkan informasi dan pengalaman secara persuasif. Penelitian ini menggunakan metode studi kasus dengan wawancara informan, yaitu dua orang influencer yang resmi digandeng BNPB sebagai relawan Gugus Tugas COVID-19. Hasil penelitian ini bahwa peran influencer memberikan dampak berarti bagi para followers-nya. Konten yang dibuat influencer dalam upaya pencegahan COVID-19, menggunakan pendekatan yang bersifat bujukan atau ajakan pada setiap kontennya disisipi edukasi dan sosialisasi pencegahan serta konten yang tidak mengandung kontroversial. Untuk menjangkau masyarakat yang tidak bisa mengakses internet, para influencer terjun ke lapangan untuk berkomunikasi secara langsung bertemu para tokoh masyarakat, publik figur hingga kepala daerah. Hal inilah terciptanya trust antara pengguna dengan pengikutnya, maka para influencer ini sukses mempunyai pengikut setia.
\end{abstract}

Kata kunci: Influencer, Komunikasi Persuasif, COVID-19

ISSN 2338 - 0861 (cetak); e-ISSN 2621 - 8712 (online)

website : http://spektrum.stikosa-aws.ac.id 


\section{PENDAHULUAN}

Perkembangan teknologi dari waktu ke waktu secara tidak langsung membentuk masyarakat sebagai pengguna dan penerima informasi. Hal ini menimbulkan perubahan proses komunikasi baik individu maupun kelompok. Salah satu perwujudan dari teknologi komunikasi adalah media sosial yang semakin mudah digunakan untuk berinteraksi dan menyebarkan informasi (Tosepu, 2018, p. 215).

Kehadiran media sosial seperti Facebook, Youtube, Twitter dan Instagram memunculkan cara komunikasi baru melalui influencer. Influencer memiliki peranan yang penting di tengah pandemi COVID-19 yang telah ditetapkan WHO (World Health Organization) sebagai pandemi global. Indonesia termasuk negara dengan jumlah Covid-19 terbanyak se-Asia Tenggara dengan totalnya 63.749 kasus pada Senin, 5 Juli 2020 (Merdeka.com, 2020). Pusat Penelitian Kependudukan Lembaga Ilmu Pengetahuan Indonesia (LIPI) menjelaskan ada tiga faktor penyebab kasus COVID-19 bertambah di Indonesia. Pertama, internal yang mana banyak masyarakat tidak mengikuti anjuran pemerintah seperti tidak beribadah secara berjamaah dan masih berkerumunan di tempat umum. Kedua, eksternal yang mana masyarakat mengonsumsi informasi dari media yang tidak kredibel di internet. Ketiga, institusional yang mana pernyataan pemerintah tidak transparan dari awal (Republika.co.id, 2020).

Influencer merupakan orang yang memiliki jumlah followers-nya banyak dan mempunyai pengaruh di media sosial. Mereka tidak hanya disebut sebagai selebgram atau youtuber bisa saja dari kalangan dokter, atlet, professional, aktivis ataupun pengusaha. Di tengah pandemi COVID-19, influencer merupakan langkah alternatif dalam memberikan informasi yang dibutuhkan publik. Artinya, influencer menjadi hal yang penting dalam menghadapi COVID-19. Dengan kebijakan terkait peraturan atau imbauan COVID-19, maka influencer menjadi pilihan untuk memberikan informasi ke masyarakat. Untuk menjawab berbagai persoalan akibat pandemi COVID-19, komunikasi persuasif menjadi pilihan dalam menyampaikan pesan ke masyarakat. Komunikasi persuasif dapat diartikan sebagai kegiatan mempengaruhi orang lain dengan melibatkan sisi psikologis komunikan, sehingga komunikan tersebut dengan sadar melakukan sesuatu atas kehendaknya sendiri (Zaenuri, 2017).

Media sosial merupakan medium internet yang memungkinkan pengguna merepresentasikan dirinya maupun berinteraksi, bekerja sama, berbagi, berkomunikasi dengan pengguna lain, dan membentuk ikatan sosial secara virtual (Nasrullah, 2017, p. 13). Artinya, pengguna media sosial bisa menciptakan atau mengkonsumsi konten dan menjalin hubungan antar pengguna. Bahkan pengguna internet terus meningkat di Indonesia pada masa pandemi. Kementerian Komunikasi dan Informatika (Kemkominfo) mengungkapkan ada peningkatan pengguna internet di pandemi yang mencapai 175 juta dari total populasi pengguna digital yang mencapai 272,1 juta orang. Di sisi lain pengguna media sosial 160 juta orang dari 272,1 juta orang pengguna jaringan digital di Indonesia (Beritasatu.com, 2020).

Instagram merupakan media sosial yang banyak digunakan oleh masyarakat Indonesia. Alasan menggunakan Instagram, yakni mencari informasi, hal ini sesuai dengan jejaring sosial Instagram yang sering kali digunakan sebagai tempat untuk menyebarkan dan berbagi informasi, serta

ISSN 2338 - 0861 (cetak); e-ISSN 2621 - 8712 (online)

website : http://spektrum.stikosa-aws.ac.id 
berinteraksi dengan orang banyak, dan juga untuk dapat mengenal lebih dekat dengan sesama penggunanya melalui foto maupun video yang diunggah (Innova, 2016). Instagram adalah media yang memberi kemudahan cara berbagi secara online fotofoto, video dan juga layanan jejaring sosial yang dapat digunakan pengguna untuk mengambil dan membagi ke teman mereka (Budiargo, 2015, p. 48). Instagram menjadi media sosial yang memiliki jumlah penggunannya mengalami peningkatan pada tahun November 2019. Jumlah pengguna aktif Instagram sebanyak 61 juta orang. Seperempat orang Indonesia adalah pengguna aktif Instagram 22,6 persen atau hampir. Data tersebut dari perusahaan analis marketing media sosial, NapoleonCat (Kumparan.com, 2019).

Pengguna Instagram tidak hanya pribadi dan kepentingan bisnis, tetapi juga digunakan sharing informasi. Influencer bisa memberikan sharing informasi sebagai bahan sosialisasi dan mitigas dalam situasi pandemi. Influencer yang fokus dengan isu COVID-19 akan memberikan pemahaman tentang bahaya COVID-19 dengan postingan berupa konten tulisan, foto dan video. Live streaming juga dimanfaatkan influencer sebagai interaktif sehingga audiens dapat langsung memberikan komentar. Sosok influencer adalah mereka yang dianggap memiliki kredibilitas, dapat dipercaya dan mudah dijangkau karena dapat terjadi interaksi (komen dan respon) (Evelina \& Handayani, 2018).

Dalam konteks COVID-19, influencer memiliki pengaruh besar untuk mempersuasi followers-nya dengan menyisipkan imbauan ke pengikutnya melalui Instagram mengenai pentinganya hidup sehat dan merubah pola hidup dengan menerapkan physical distancing, work from home, menggunakan masker, mencuci tangan dan mengikuti imbauan pemerintah. Komunikasi persuasi menggunakan media seperti teknologi komputer termasuk internet dan disebut computer-mediated communication (CMC) (Puji Hartanti, 2018). Pada dasarnya, CMC sama seperti komunikasi face to face yang mana dibantu oleh media untuk melakukan bentuk komunikasi tatap muka. Cakupan dari CMC itu sendiri termasuk sistem obrolan (chatting), World Wide Web (WWW), termasuk sistem tekstual, grafis, fotografi, audio, dan video disamping aspek-aspek hyperlink, CMC juga mencakup berbagi video seperti Youtube dan sistem jejaring sosial dan sistem pencarian pertemanan seperti facebook dan lain sebagainya (Arnus, 2015).

Kehadiran influencer menjadi salah satu langkah cepat yang langsung ke publik dalam memberikan informasi hingga imbauan terkait COVID-19. Influencer mempunyai peran sentral dalam memberikan proteksi dini dalam melindungi masyarakat. Dengan demikian, keberadaan influencer menjadi cara alternatif untuk menangani COVID-19. Hal ini berbeda yang biasanya seorang influencer dipakai jasanya untuk mengenalkan produk, justru influencer membantu memberikan informasi positif. Influencer merupakan seseorang yang perkataannya dapat mempengaruhi orang lain (Sugiharto et al., 2018).

Penelitian ini berfokus pada menggali informasi dari influencer yang resmi digandeng Badan Nasional Penangulangan Bencana (BNPB). Peneliti memilih informan, yaitu dr. Tirta Mandira Hudhi merupakan dokter sekaligus pengusaha dengan pengikut Instagram-nya 1.626.305. Kemudian, Muh. Arief Rosyid merupakan tokoh milenial dan aktivis kepemudaan dengan pengikut Instagram-nya sebanyak 21.718 (https://www.instagram.com/dr.tirta/ dan

ISSN 2338 - 0861 (cetak); e-ISSN 2621 - 8712 (online)

website : http://spektrum.stikosa-aws.ac.id 
https://www.instagram.com/ariefrosyid.id/ diakses pada Rabu, 5 Agustus 2020). Keduanya tidak hanya menggunakan Instagram untuk menggungah foto atau video saja, tetapi juga digunakan live Instagram yang membahas persoalan COVID-19. Hal ini mencerminkan bahwa mereka telah dikenal khalayak di lingkup warga maya (netizen) khususnya pengguna Instagram. Selain itu, mereka berdua menggungah foto atau video secara bersamaan terkait pertemuanya dengan kepala daerah, tokoh masyarakat, publik figur hingga membagikan paket bantuan masyarakat dan tenaga medis yang diposting melalui akun Instagram-nya masing-masing.

Penelitian ini akan fokus menggali informasi dari relawan Gugus Tugas COVID19 menjadi influencer yang memberikan pesan positif dan edukaif terkait pencegahan COVID-19. Maka penelitian ini ingin melihat bagaimana peran influencer sebagai komunikasi persuasif untuk pencegahan COVID-19? Tujuan penelitian ini ingin menjawab pertanyaan penelitian, yakni untuk mengetahui peran influencer sebagai komunikasi persuasif untuk pencegahan COVID-19.

\section{METODE PENELITIAN}

Paradigma dalam penelitian ini menggunakan post-positivistik. Pendekatan penelitian ini menggunakan kualitatif karena tidak berkaitan dengan angka-angka. Metode penelitian ini adalah studi kasus instrumental. Jenis studi kasus ini dijadikan sebagai sarana untuk memahami hal lain di luar kasus atau kerangka konseptual yang tersusun dari konsep yang saling berkaitan pada kerangka teoritis (Ananda, 2018).

Pengumpulan data dilakukan dengan dengan mengambil sampling informan dari influencer, yaitu dr.Tirta Mandira Hudhi sebagai informan pertama dan Muh. Arief Rosyid sebagai informan kedua. Wawancara dilakukan pada 1 - 2 Agustus 2020 melalui tatap muka dan telepon seluler. Peneliti juga melakukan dokumentasi dan observasi seperti mengamati langsung terhadap unggahan akun Instagram, @dr.tirta dan @ariefrosyid.id berupa video dan foto serta komentar audiens.

Dari data yang sudah dikumpulkan, kemudian data tersebut diolah dan ditelaah. Terdapat tiga tahap aktivitas dalam analisis data yaitu: (1) Reduksi Data. Mereduksi data berarti merangkum, memilih hal-hal pokok yang fokus pada hal-hal penting. Data yang sudah direduksi akan memberikan gambaran yang lebih jelas dan mempermudah peneliti dalam mengumpulkan data, (2) Penyajian Data, yaknik dilakukan dalam bentuk uraian singkat, bagan, hubungan antar katagori, flowchart dan sejenisnya. Miles dan Huberman mengatakan bahwa yang paling sering digunakan untuk menyajikan data dalam penelitian kualitatif dengan teks yang bersifat naratif (3). Kesimpulan, dalam penelitian kualitatif merupakan temuan baru yang sebelumnya belum pernah ada. Temuan terdapat berupa deskripsi atau gambaran suatu objek yang sebelumnya masih remangremang atau gelap sehingga setelah diteliti menjadi jelas, dapat berupa kausal atau interaktif, hipotesis atau teori (Sugiyono, 2011, pp. 247-252).

\section{HASIL PENELITIAN DAN PEMBAHASAN}

Penelitian ini menemukan beberapa hal penting yang dibahas secara komperhensif dan memperoleh perspektif baru tentang peran influencer dalam komunikasi persuasif di media sosial Instagram. Pembahasan dalam penelitian ini fokus pada peran dr. Tirta dan Arief Rosiyd melalui Instagram-nya masing-masing dalam

ISSN 2338 - 0861 (cetak); e-ISSN 2621 - 8712 (online)

website : http://spektrum.stikosa-aws.ac.id 
mengkomunikasi secara persuasi dan cara menarik perhatian followers. Selain itu, peneliti juga akan melihat tanggapan followers @dr.tirta dan @ariefrosyid.id mengenai konten COVID-19.

\section{PERAN INFLUENCER DI PANDEMI COVID-}

\section{9}

Tugas influencer adalah memberikan review yang dapat memberikan kepercayaan dengan konten yang menarik kepada followers-nya. Kepercayaan atau trust tersebut pun akan terlihat dalam bentuk interaksi secara langsung lewat kolom komentar pada post tersebut (Hanindharputri \& Putra, 2019). Maka influencer memiliki peran besar menggunakan media sosial sebagai wadah bagi mereka mengekspresikan diri dan membangun komunikasi yang bertujuan mempengaruhi pengikutnya agar apa yang dikatakannya bisa diikuti atau dilakukan. Peranan influencer dalam mengkomunikasikan pesan melalui Instagram ini, bisa dikatakan sebagai salah satu bentuk komunikasi massa dan mass-self communication yang, karena apa yang mereka sampaikan dapat mempengaruhi para pengikutnya dan memberikan informasi yang dibutuhkan oleh para pengikutnya (Anjani \& Irwansyah, 2020).

Influencer dilibatkan BNPB agar informasi terkait pencegahan COVID-19 ke publik. Mereka diminta mengkampanyekan hidup bersih dan hidup sehat, menerapkan physical distancing dan tetap di rumah. Pesan ini yang diteruskan ke followers atau pengikut dari influencer media sosial.

Setelah dilakukan penelitian secara literatur dan wawancara secara langsung bahwa akun Instagram @dr.tirta dan @ariefrosyid.id memberikan pengaruh terhadap para followers-nya baik secara langsung maupun tidak langsung. Tirta berpandangan bahwa masyarakat harus tahu bahaya COVID-19 bagi kesehatan. Oleh karena itu, konten yang disampaikannya lebih mengarah kewaspadaan.

"Ya COVID-19 itu kan sesuatu yang harus kita waspadai karena ini menyangkut kesehatan global. Dan ini sebenarnya yang kita sampaikan ke publik. Kalau ini tidak tersampaikan ini bahaya Mas" (Tirta Mandira Hudhi, dalam wawancara pada Sabtu, 1 Agustus 2020).

"COVID-19 itu semua negara di dunia ini mengalami terkena dampak COVID19 baik kesehatan maupun ekonomi. COVID-19 ini kan virus seperti pandemi sebelumnya yang kena dampak kesehatan dan ekonomi. COVID-19 itu virus yang baru hampir semua negara mengalami dan terkena. Kurang lebih virus yang harus kita waspadai dan tidak paranoid sendirlah" (Muh. Arief Rosyid, dalam wawancara pada Minggu, 2 Agustus 2020).

Selanjutnya, Tirta menyadari bahwa media sosial sebagai wadah yang tepat untuk menyalurkan informasi terkait pencegahan COVID-19. Tirta mengaku masyarakat harus memperoleh informasi yang mereka belum miliki seperti imbauan pemerintah dan anjuran pemerintah. Tirta mengatakan bahwa membujuk atau mengajakan followers-nya untuk mengikuti perkataannya memang tidak semudah itu. Namun yang terpenting informasi yang disampaikan ke pengikutnya tidak melenceng. Apalagi banyak informasi hoaks beredar di media sosial.

"Kita sebagai masyarakat harus ikut protokol kesehatan sesuai anjuran

ISSN 2338 - 0861 (cetak); e-ISSN 2621 - 8712 (online)

website : http://spektrum.stikosa-aws.ac.id 
tenaga kesehatan dan pemerintah. Peran ini yang kita mainkan. Kita menyampaikan informasi yang terpenting tidak ada bias saja Mas. Ini penting banget" (Tirta Mandira Hudhi, dalam wawancara pada Sabtu, 1 Agustus 2020).

Berbeda dengan Tirta, justru Arief yang melakukan dua pendekatan, yaitu secara online dan offline yang bertemu langsung. Menurut Arief, permasalahan COVID-19 ada di komunikasi yang belum sampai ke masyarakat dan kemampuan literasi masih rendah. Untuk meluruskan informasi hoaks di masyarakat, dibutuhkan juga komunikasi tatap muka secara langsung.

"Ya memang di Makassar di Jawa Tengah dan Jawa Barat dan Jawa Timur memang informasi hoaks ini domianan. Misalnya, ada pengambilan jenazah memang info berkembang bahwa rumah sakit dan dokter punya keuntungan justfikasi dapat insentif dan lain-lain. Padahal itu enggak. Misinformasi, kita terlalu prematur ada ratusan dokter yang terkena, terlalu naif juga kita menggenaralisir ke semua. Menurut saya peran kita itu meng-counter, saya bilang ke temanteman sekecil apapun kita untuk menyebarkan kebaikan, virus kebaikan itu harus masif daripada COVID-19 ini salah satu memproduksi narasi-narasi yang positif sehingga hoaks ini rasa frustasi seperti ini kita harus gotong royong, distribusi sekecil-kecil apapun informasi baik harus kita teruskan jangan kalah sama virus negatif itu baik itu hoaks maupun COVID-19 itu" (Muh. Arief Rosyid, dalam wawancara pada Minggu, 2 Agustus 2020).
Influencer mempunyai peran yang sangat besar dalam menyampaikan pesan terhadap suatu produk tertentu. Bentuk komunikasi ini seperti antara influencer dan followers-nya disebut sebagai mass self communication karena terjadi interaksi langsung yang dibuat oleh influencer dengan para pengikutnya. Salah satu contohnya postingan@dr.tirta di bawah ini:

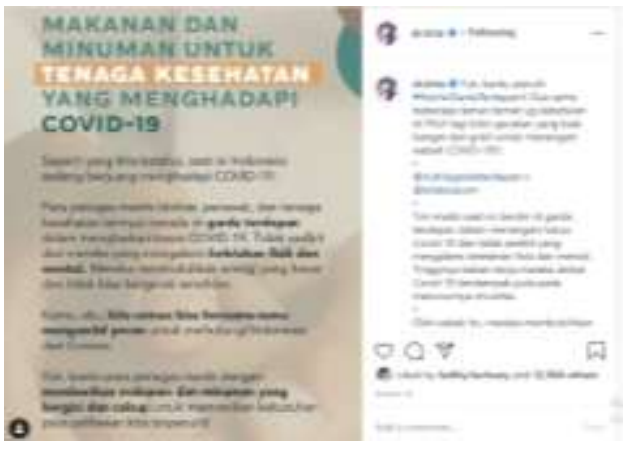

Figure 1 : Postingan Instagram @dr.tirta Source:https://www.instagram.com/p/B937_3BqfE/

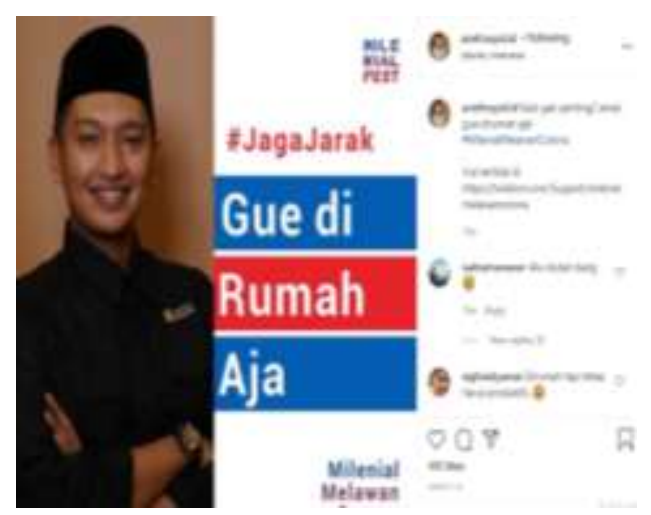

Figure 2: Postingan Instagram @ariefrosyid.id Source: https://www.instagram.com/p/B-E-1GgySw/

Untuk mewujudkan mass self communication, konten ini mengajak followers akun Instagram @dr.tirta dan @ariefrosyid.id untuk membantu berdonasi ke tenaga

ISSN 2338 - 0861 (cetak); e-ISSN 2621 - 8712 (online)

website : http://spektrum.stikosa-aws.ac.id 
kesehatan yang sedang menangani pasien COVID-19 dan mengimbau masyarakat untuk tetap di rumah. Sehingga konten yang bersifat emosional mampu membangun simpati dan kepercayaan dari pengikutnya.

Sementara, konten-konten terkait edukasi dan pencegahan COVID-19 dibuat secara ilmiah. Tirta menegaskan edukasi ini penting agar masyarakat tidak salah dalam mengambil tindakan di tengah pandemi COVID-19.

"Kita membuat konten dengan membantunya dengan data dan ilmiah. Tidak ada yang mengada-ngada. Sehingga masyarakat dapat informasi yang benar. Begitu Mas." (Tirta Mandira Hudhi, dalam wawancara pada Sabtu, 1 Agustus 2020).

Konten yang dibuat Arief melalui riset dan melihat situasi di lapangan. Ia mengatakan, apa yang disampaikannya selalu informasi positif ke publik dan menghindari konten konterversial. Sebab, hal ini akan berdampak pada reputasi dirinya sebagai aktvisi maupun pengurus dewan masjid Indonesia.

"Oh... tentu mengatakan sesuatu saja berpikir apalagi di media sosial yang jejaknya abadi pasti kita berfikir dan ada konsekuensinya. Alhamdulillah responsnya selalu positif dan saya memang menyampaiakan apa adanya dan informasi yang positif. Saya bukan membuat rumit. Terkadang postingan kita hanya untuk eksistensi dan lainlain. Saya menghindari itu, saya sadari ketika terjun ke masyarakat melihat probelm masyrakat sangat kompleks. Harusnya kita membuat masalah semakin ringan" (Muh. Arief Rosyid, dalam wawancara pada Minggu, 2 Agustus 2020).”

Penting bagi influencer untuk memilah-milah pesan yang akan disampaikan ke publik. Influencer perlu mempertimbangkan dampak yang ditimbulkan dari konten yang sudah disebarluaskan. Utamannya konten yang tidak membuat gaduh dan konterversial. Menurut Pengamat Media Sosial dari Komunikonten, Hariqo Wibawa, influencer dianggap memiliki pengaruh salah satu ukurannya followers karena itu bagian massa yang dimiliki. Ia berpendapat membuat konten lebih pendekatan mengajak seperti narasi dibangun bukan pribadi tapi ke sosial (Rilis.id, 2020). Pesan ini yang disampaikan tidak terlalu berat, terpenting publik paham dan bisa melaksanakannya. Walapun konten dikontrol oleh pengguna, sebaiknya perlu meriset isu dan merespons berdasarkan data dan fakta secara ilmiah.

Salah satu contoh kegaduhan influencer akibat kontennya menuai kecaman dan kritik ialah selebgram Sarah Salsabila alias Sarah Keihl. Dalam postingan Instagramnya, ia memposting sebuah video dengan menawarkan lelang keperawanan yang dibuka harga Rp 2 Miliar. Uang tersebut akan didonasikan ke petugas medis dan relawan penanganan COVID-19. Influencer seharusnya memberikan contoh yang baik bukan membuat konten yang memperkeruh suasana. Konten yang hendak diunggah di media sosial harus memikirkan dampak yang ditimbulkan apalagi di tengah pandemi saat itu.

Meski demikian, bagi Arief, informasi yang diterima influencer Gugus Tugas COVID-

ISSN 2338 - 0861 (cetak); e-ISSN 2621 - 8712 (online)

website : http://spektrum.stikosa-aws.ac.id 
19 harus melalui koordinasi pihak tim komunikasi BNPB agar informasi yang disampaikan ke publik tidak memunculkan kegaduhan. Tirta menegaskan bahwa informasi yang disampaikan oleh influencer harus berdasarkan data dan fakta.

"Kita punya grup influencer dari BNPB ada informasi ngirim ke WA (WhatsApp) itu bisa menyampaikan pesan ada di tengah-tengah masyarakat. Begitu juga sebaliknya dari influencer ada info dari mana saja kita report ke BNPB. Jadi informasinya mekanismenya chcek and balance-nya jalan. kita saling koordinasi" (Muh. Arief Rosyid, dalam wawancara pada Minggu, 2 Agustus 2020).

"Kita membantu menyampaikan informasi ke masyarakat dengan data dan ilmiah." (Tirta Mandira Hudhi, dalam wawancara pada Sabtu, 1 Agustus 2020).

Dengan demikian, influencer tidak hanya mampu mempengaruhi pengikutnya atau khalayak tetapi juga mereka dianggap sebagai panutan atau orang yang dicontohi sikap dan prilakunya. Dalam konteks pandemi COVID-19, influencer bisa berperan membuat suasana menjadi kondusif dan tidak memunculkan ketakutan masyarakat.

\section{KOMUNIKASI PERSUASIF INFLUENCER DI MEDIA SOSIAL}

Peneliti melakukan wawancara kepada Tirta Mandira Hudhi selaku pemilik akun Instagram @dr.tirta. Tirta mengaku dirinya langsung mengelola dan memposting baik video maupun foto serta caption di
Instagram-nya. Selain membuat konten di media sosial yang diikuti followers-nya oleh 1,6 juta, Tirta di-briefing dan berkoordinasi dengan Tim Komunikasi Publik Gugus Tugas Nasional Percepatan Penanganan COVID-19. Tentunya, konten yang dibuatnya tidak hanya berdasarkan pribadi saja tetapi juga mewakili instansi / lembaga. Seperti, hasil wawancaranya dengan media massa, live IG bersama publik figur, foto pembagian donasi dan lain-lain. Hal ini menunjukan bahwa Tirta menjadi produsen dan gatekeeper.

"Sebelum kita menyampaikan informasi ke publik, kita ada breafing karena kita tim komunikasi biar informasinya itu terarah dan sampai ke masyarakat. Kita menyampaikan data dan sesuai fakta di lapangan" (Tirta Mandira Hudhi, dalam wawancara pada Sabtu, 1 Agustus 2020).

Dalam wawancaranya, Tirta menegaskan konten yang dipostingnya juga berdasarkan riset agar informasi yang diterima ke publik tepat sasaran. Sebelum menuliskan caption dan mengunggah foto atau video di Instagram, hal yang diperhatikan, yakni dampak bagi para followers-nya di media sosial Instagram. Foto atau video dengan caption menarik dijadikan sebagai alat untuk menyampaikan pesan tentang edukasi COVID-19 akan mempermudah para pengikutnya.

"Kita menyampaikan informasi secara tepat saja Mas agar masyarakat teredukasi dan tahu hidup sehat. Sebenarnya siapapun bisa memberikan informasi ke masyarakat. Kita riset-

ISSN 2338 - 0861 (cetak); e-ISSN 2621 - 8712 (online)

website : http://spektrum.stikosa-aws.ac.id 
riset juga persoalan sekarang. Mas bisa lihat (konten saya)" (Tirta Mandira Hudhi, dalam wawancara pada Sabtu, 1 Agustus 2020).

Hal ini menunjukan, Tirta tidak ingin informasi yang disampaikannya salah dan memberikan dampak buruk bagi pengikutnya. Tirta menegaskan, pesan yang disampaikan terkait COVID-19 mengandung edukatif dan tidak ada unsur menakut-nakuti. Selain itu, foto dan video di akun Instagram @dr.tirta, mengunggah kegiatan-kegiatan berkaitan dirinya menjadi relawan Gugus Tugas COVID-19. Kegiatannya pun berdasarkan semangat yang dibawanya, yakni seputar kegiatan penanganan COVID19. Para Influencer ini akan menghindari kata-kata negatif.

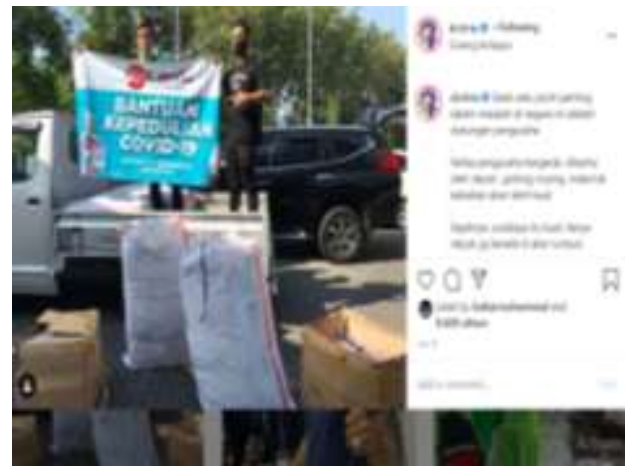

Figure 3 : Postingan Instagram @dr.tirta Sumber:https://www.instagram.com/p/CCaVfHwBRN e/

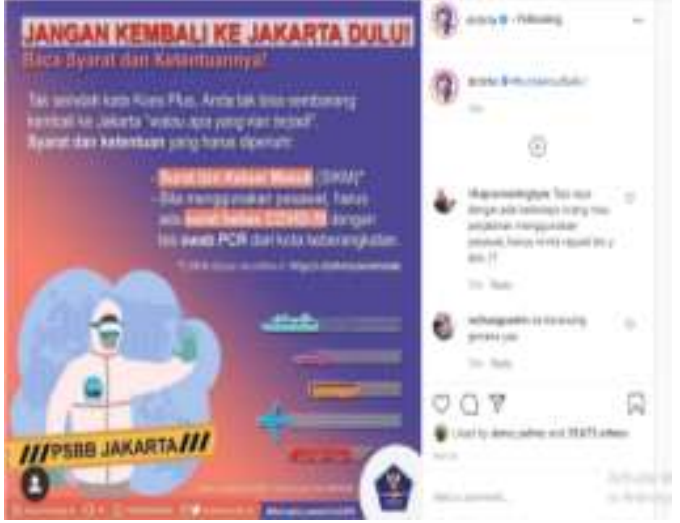

Figure 4 : Postingan Instagram @dr.tirta Source:https://www.instagram.com/p/CAm5JZ6 hxsM/

Dalam mempersuasi publik, Muh. Arief Rosyid menggunakan konsep heliks (berputar ke kiri atau ke kanan, dengan sebuah tumpuan di tengah) dengan menggunakan berbagai instrumen. Ia memulai mempersuasif publik dengan kegiatan mengecek dan memantau masjidmasjid. Ia mengatakan, masjid merupakan tempat yang bisa membantu dan menyalurkan bantuan ke masyarakat. Kegiatan ini kemudian, ia posting di akun Instagram-nya sebagai laporan pertanggungjawaban donasi yang dikumpulkan bersama netizen.

"Kita persuasi masyarakat dengan keteladanan dari pemerintah dan publik figurnya yang tecermin dari prilaku sehari-harinya. Saya pakai teman-teman influencer, teman aktivis, kita dorong mereka memberi contoh apa yg disampaikan, ini viral di media sosial dan media mainstream. Dan Pak Doni bilang konsep heliks (berputar ke kiri atau ke kanan, dengan sebuah tumpuan di tengah) yang dilakukan pemerintah, masyarakat, pengusaha dan media. Peran-peran itu yang kita

ISSN 2338 - 0861 (cetak); e-ISSN 2621 - 8712 (online)

website : http://spektrum.stikosa-aws.ac.id 
dorong, kita cari anak mudanya siapa, kita cari tokohnya siapa, kita kasih peran dan tugas. Kenapa saya memulai dari masjid. Pertama saya terjun dunia relawan ini saya aktif di dewan masjid. Kedua masjid selama ini tidak hanya ibadah tapi masjid di zaman Rasulluah SAW itu fungsi sosial dan ekonomi. Ketika COVID-19 muncul, banyak masjid ditutup dan banyak juga masjid memainkan peran misalnya menstabilkan harga pokok, di masjid Tangerang Selatan penyemporotan dan lain-lain" (Muh. Arief Rosyid, dalam wawancara pada Minggu, 2 Agustus 2020).

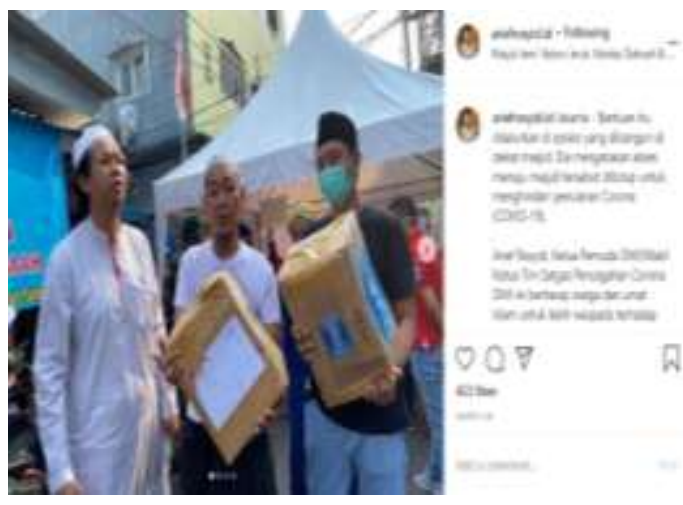

Figure 5 : Postingan Instagram @ariefrosyid.id Source: https://www.instagram.com/p/BRi2oBA3kX/

Dalam upaya mempengaruhi publik, media sosial Instagram memiliki fungsi sebagai saluran pengguna untuk mempersuasif dengan orang lain melalui gambar atau video. Maka, komunikasi persuasif influencer secara ajakan telah mampu membangun trust antara pengguna dengan pengikutnya. Apalagi Tirta merupakan dokter yang mewakili generasi muda, sehingga pesannya pun bisa diterima.
Dengan demikian, komunikasi persuasif yang Tirta dan Airef lakukan dalam upaya penanangan COVID-19 diutamakan konten yang berdasarkan data ilmiah dan sesuai fakta di lapangan. Pendekatan yang dilakukannya lebih bersifat bujukan pada setiap kontennya disisipi edukasi dan sosialisasi pencegahan COVID-19.

\section{TANGGAPAN FOLLOWERS TERHADAP UNGGAHAN KONTEN}

Konten media sosial Instagram dari @dr.tirta dan @ariefrosyid.id mengenai informasi COVID-19 menuai berbagai komentar dari followers. Pada dasarnya, semua komentar dari followers-nya menunjukan respons yang baik dan mendukung konten yang bersifat kemanusiaan. Berikut tanggapan dari followers @dr.tirta dan @ariefrosiyd.id.
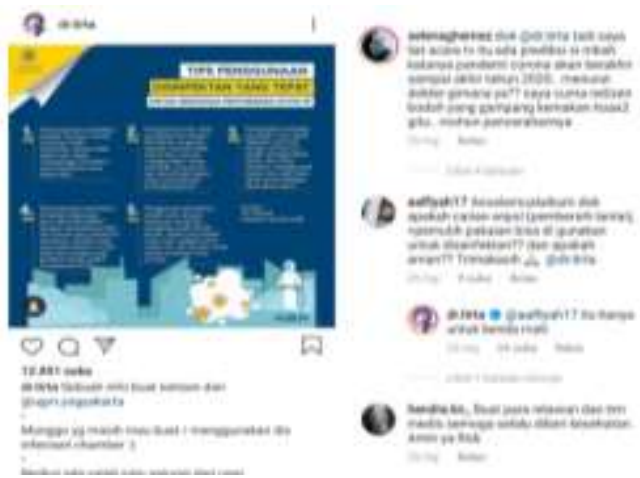

Figure 6 : Komentar Pengikut @dr.tirta Source:https://www.instagram.com/p/B_Ho4pA BmXc/?utm_source=ig_web_copy_link

Mayoritas followers@dr.tirta memberikan komentar positif terhadap konten yang membahas Tips Penggunaan Disinfektan yang Tepat untuk Pencegahan Penyebaran COVID-19. Hal ini menunjukan sebagian besar konten yang diposting @dr.tirta berhasil dan mudah dipahami bahkan ada yang memberi semangat. Jika

ISSN 2338 - 0861 (cetak); e-ISSN 2621 - 8712 (online)

website : http://spektrum.stikosa-aws.ac.id 
dilihat komentar dari akun @hendra.kn_ "Buat para relawan dan tim medis semoga selalu diberi kesehatan. Amin ya Rob" Komentar tersebut memberi semangat ke dr.Tirta untuk terus melakukan edukasi dan memberi informasi pencegahan COVID-19. Sementara akun @aalifiyah17 bertanya "Assalamualaikum dok apakah cairan wipol (pembersih lantai), + pemutih pakaian bisa di gunakan untuk disenfektan?? dan apakah aman?? Trimakasih". Kemudian pertanyaan tersebut langsung dijawab @dr.tirta "Itu hanya untuk benda mati". Hal ini menunjukan adanya interaksi agar konten yang disampaikan lebih jelas. Karena itu, terlihat jelas bahwa akun @dr.tirta berhasil membangun trust terhadap followers khususnya konten edukasi berkaitan pencegahan COVID-19.

Selanjutnya konten akun @ariefrosyid.id yang memposting informasi mengenai pembagian paket sembako bagi masyarakat yang terdampak COVID-19. Dalam konten tersebut tampak para influencer sedang membagikan paket sembako. Selain itu, caption di konten tersebut juga mengajak followers-nya untuk saling membantu masyarakat.

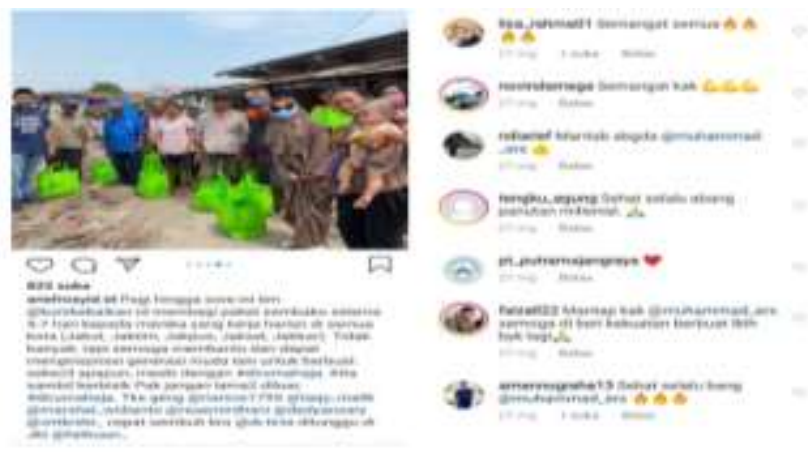

Figure 7 : Komentar Pengikut @ariefrosyid.id

Source:https://www.instagram.com/p/BT0S vXAiAd/?utm_source=ig_web_copy_link
Mayoritas di kolom komenter akun @ariefrosyid.id memberikan tanggapan positif dan dukungan terhadap konten yang membagikan paket sembako. Perhatikan komentar@ @Faizall22 "Mantap kak @muhammad_ers (@ariefrosyid.id) "semoga di beri kesehatan kekuatan berbuat lebih banyak". Senada dengan komentar @tengku_agung "Sehat selalu abang panutan mileniall" dan komentar @amannugraha13 "Sehat selalu bang @muhammad_ers". Sementara komentar @lisa_rahma01 "Semangat semua" dan koementar @noviandamega "Semangat kak". Komentar tersebut menunjukan bahwa akun @ariefrosyid.id mendapatkan doa agar tetap sehat dan bersemangat dalam membantu masyarakat yang terkena dampak COVID-19.

Dengan demikian, akun @ariefrosyid.id berhasil membangun trust dan dukungan terhadap followers-nya yang mana keberhasilan itu terlihat dari mayoritas komentar positif. Sehingga akun @ariefrosyid.id mampu membangun rasa puas terhadap followers-nya dengan berbagai informasi yang secara umum memperlihatkan konten saling membantu dan gotong royong.

\section{KESIMPULAN}

Berdasarkan hasil penelitian yang dipaparkan bahwa peran influencer di pandemi COVID-19 melalui media sosial memberikan dampak berarti bagi para followers-nya. Media sosial menjadi wadah bagi masyarakat untuk mendapatkan informasi akurat secara ilmiah dan pengalaman melalui foto dan video serta kontennya dapat dipertanggungjawabkan.

Influencer dapat diartikan sebagai orang yang dianggap opinion leader dalam

ISSN 2338 - 0861 (cetak); e-ISSN 2621 - 8712 (online)

website : http://spektrum.stikosa-aws.ac.id 
menentukan suatu topik atau membahas satu persoalan. Konten yang dibuat di influencer dalam upaya pencegahan COVID-19, menggunakan pendekatan yang bersifat bujukan atau ajakan pada setiap kontennya disisipi edukasi dan sosialisasi pencegahan COVID-19 serta konten yang tidak memperkeruh suasana (konterversial). Untuk menjangkau masyarakat yang tidak bisa mengakses internet, para influencer terjun ke lapangan untuk berkomunikasi secara langsung bertemu para tokoh masyarakat, publik figur hingga kepala daerah. Hal ini sebagai upaya mencari solusi untuk menekan angka laju COVID-19.

Hal inilah terciptanya trust antara pengguna dengan pengikutnya. Sehingga, apabila influencer konsisten memberikan konten yang berdampak kehidupan followersnya, maka akan memunculkan pengikut setia khususnya dalam memberikan pesan positif mengenai pencegahan COVID-19.

\section{DAFTAR PUSTAKA}

Ananda, L. D. (2018). Dinamika Trust pada Pemasaran Online di Media Sosial. Jurnal Komunikasi Indonesia, 6(1). https://doi.org/10.7454/jki.v6i1.8625

Anjani, S., \& Irwansyah, I. (2020). Peranan Influencer Dalam Mengkomunikasikan Pesan Di Media Sosial Instagram [the Role of Social Media Influencers in Communicating Messages Using Instagram]. Polyglot: Jurnal Ilmiah, 16(2), 203. https://doi.org/10.19166/pji.v16i2.192 9

Arnus, S. H. (2015). Computer Mediated Communication (CMC), Pola Baru Berkomunikasi. Al-Munzir, 8(2), 275-
289. https://doi.org/http://dx.doi.org/10.31 332/am.v8i2.744

Beritasatu.com. (2020). WFH, Pengguna Internet Naik 10 Persen. Www.Beritasatu.Com. https://www.beritasatu.com/jajasuteja/nasional/629099/wfh-penggunainternet-naik-10-persen

Budiargo, D. (2015). Berkomunikasi Ala Generation. Kompas Gramedia.

Evelina, L. W., \& Handayani, F. (2018). Penggunaan Digital Influencer dalam Promosi Produk (Studi Kasus Akun Instagram @bylizzieparra). Warta ISKI, 1(01), 71 . https://doi.org/10.25008/wartaiski.v1i 01.10

Hanindharputri, M. A., \& Putra, I. K. A. M. (2019). Peran Influencer dalam Strategi Meningkatkan Promosi dari Suatu Brand ( The Role of Influencer in Strategies to Increase Promotion of a Brand ). Seminar Nasional Sandykala, 29, 335343. http://eproceeding.isidps.ac.id/index.php/sandyakala/article/ view/73

Innova, E. I. (2016). Motif dan Kepuasan Pengguna Instagram di Komunitas Instameet Indonesia. Jurnal $E$ Komunikasi, 4(1), 1-11. http://publication.petra.ac.id/index.php /ilmu-komunikasi/article/view/4851

Kumparan.com. (2019). Jumlah Pengguna Instagram di Indonesia Capai 61 Juta. Www.Kumparan.Com. https://kumparan.com/kumparantech/j umlah-pengguna-instagram-diindonesia-capai-61-juta-1sVVLzdQ00T

Merdeka.com. (2020). Indonesia Masih

ISSN 2338 - 0861 (cetak); e-ISSN 2621 - 8712 (online)

website : http://spektrum.stikosa-aws.ac.id 
Peringkat Pertama Kasus Covid-19

Tertinggi di ASEAN. Www.Merdeka.Com. https://www.merdeka.com/peristiwa/i ndonesia-masih-peringkat-pertamakasus-covid-19-tertinggi-di-asean.html

Nasrullah, R. (2017). Media Sosial: Perspektif Komunikasi, Budaya dan Sositeknologi. Remaja Rosdakarya.

Puji Hartanti, L. E. (2018). Komunikasi Orang Muda Di Sosial Media Sebagai Influencer. WACANA, Jurnal Ilmiah Ilmu Komunikasi, 17(2), 152.

https://doi.org/10.32509/wacana.v17i2 .599

Republika.co.id. (2020). Tiga Penyebab Indonesia Sulit Atasi Pandemi Covid-19. Www.Republika.Co.Id. https://republika.co.id/berita/qadh904 09/tiga-penyebab-indonesia-sulit-atasipandemi-covid19

Rilis.id. (2020). Pengamat Sebut Buzzer Lebih Efektif Tangani Corona ketimbang Influencer. http://m.rilis.id/pengamatsebut-buzzer-lebih-efektif-tanganicorona-ketimbang-influencer

Sugiharto, S. A., Ramadhana, M. R., Psi, S., \& Psi, M. (2018). PENGARUH KREDIBILITAS INFLUENCER TERHADAP SIKAP PADA MEREK (Studi pada Mahasiswa Fakultas Komunikasi dan Bisnis Universitas Telkom). Jurnal Ilmu Politik Dan Komunikasi, VIII(2). https://doi.org/http//www.doi.ac.id/10 .34010/JIPSI.V8I2.1333

Sugiyono. (2011). Metode Penelitian Kuantitatif Kualitatif R\&D. Alfabeta.

Tosepu, Y. A. (2018). Media Baru Dalam Komunikasi Politik (Komunikasi Politik di Dunia Virtual). CV Jakad. https://books.google.co.id/books?id=tF
nYDwAAQBAJ\&pg=PA215\&lpg=PA215\& $\mathrm{dq}=$ Salah+satu+perwujudan+dari+tekno logi+komunikasi+adalah+media+sosial+ yang+semakin+mudah+digunakan+untu k+berinteraksi+dan+menyebarkan+info rmasi\&source=bl\&ots=Rxnc4zzshX\&sig= ACfU3U0fWuzGf

Zaenuri, A. (2017). Teknik Komunikasi Persuasif Dalam Pengajaran. JALIE: Journal of Applied Lingustic and Islamic Education, 1, 41-67. https://doi.org/http://dx.doi.org/10.33 754/jalie.v1i1.83

ISSN 2338 - 0861 (cetak); e-ISSN 2621 - 8712 (online)

website : http://spektrum.stikosa-aws.ac.id 